\title{
Between the Mount of Transfiguration and Jerusalem and beyond: The chiastic structure of Matthew 17:14-20:34
}

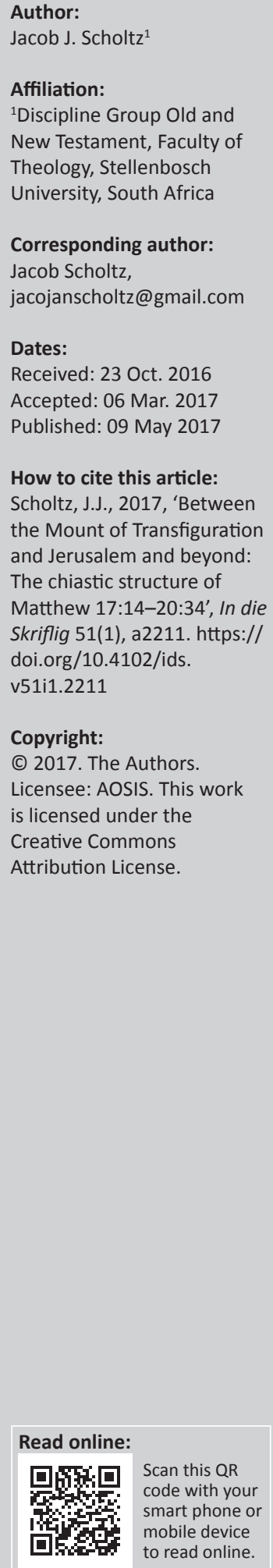

\begin{abstract}
In this article, a chiastic structure in Matthew 17:14-20:34 is identified, evaluated and discussed. This structure highlights the movements of Jesus between the Mount of Transfiguration and Jerusalem as he is on his way to the cross to provide forgiveness of sins. However, this chiastic structure may also be considered in its wider, prophetic context. The structure of Matthew 17:14-20:34 fits into the larger thought or movement of Matthew 16:28-25:46. This shows Jesus' movements from the Mount of Transfiguration to Jerusalem and beyond - not only during his first advent, but also at his second coming.
\end{abstract}

\section{Introduction}

Using different organising principles to analyse a text such as the Gospel of Matthew will plausibly result in the identification of different structures for the same passage. From a structuring perspective, however, Matthew 16-20 (or parts thereof) is in a class of its own, especially regarding the boundaries of this section. Does a new section start at $16: 13^{1}$ or at 16:21 and, if so, does it extend to 17:27, to 19:1, or perhaps even as far as 20:34? Or should 13:53-17:27 rather be viewed as a long narrative section, followed by a discourse in 18:1-35 and then by a narrative extending to 20:34, or to 22:46 or perhaps even as far as 23:39? Few other passages elicit as many different views regarding its structure as Matthew 16-20 (or parts thereof) does. Table 1 presents at least seven different ways, based on various theories about its structure, in which this passage could be depicted.

Not all analyses of text structure are the result of an overarching organising principle. Some topical studies focus on the structuring of the contents of individual sections without necessarily stating how such sections or their structure fit into the larger thought or movement of Matthew's Gospel as a whole (cf. Bauer 1988:11). For example, and relevant to Matthew 16-20, McClister (1996:549-558) sees a chiastic structure in 17:22-20:19, but does not say how this links up with the surrounding chapters of Matthew or the Gospel as a whole. Be that as it may, all these different structuring proposals clearly show that the first criterion of Blomberg (1989:5) for detecting an extended chiasmus has been met, as there is 'a problem in perceiving the structure of the text in question, which more conventional outlines fail to resolve'.

The first purpose of this article is to identify, evaluate and briefly discuss a chiastic structure in 17:14-20:34. The second purpose is to show how this chiastic structure fits into the larger thought or movement of 16:28-25:46. This may, perhaps, help to identify an overarching structuring principle.

\section{A chiastic structure in Matthew 17:14-20:34 identified and evaluated}

After being declared God's unique Son, and having again veiled his glory (cf. 17:1-13), Jesus moves down the Mount of Transfiguration and towards Jerusalem, where he will be betrayed, suffer, die and be resurrected on the third day, 'thus establishing a pattern of humility for his followers' (Carson 1995:395). ${ }^{2}$ Between the glorious transfiguration and ultimate glory in Jerusalem lies a path of suffering, humility and service, but, finally, rewards in the Kingdom. That 17:14-20:34 can be viewed as a rhetorical unit is evidenced by two miracles that 1.References to Matthew will be indicated only by chapter and verse numbers.

2.The glory of the Son of God was veiled at his incarnation and again on the Mount of Transfiguration 
Table 1: The implications of different organising principles for the structure of Matthew 16-20.

\begin{tabular}{|c|c|c|c|}
\hline Organising principle & Key & Proponents & $\begin{array}{l}\text { Implications for the structure of Matthew } \\
16-20 \text { (or parts thereof) }\end{array}$ \\
\hline Narrative-plot outline & 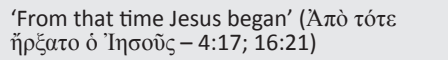 & Kingsbury (1975:1-37), Bauer (1988:97) & $16: 21-20: 34$ \\
\hline Markan and/or geographical approach & $\begin{array}{l}\text { Overall plan of Mark and/or geographical } \\
\text { movement }\end{array}$ & Morris (1992:vii-viii) & $13: 53-18: 35$ \& 19:1-20:34 \\
\hline \multirow[t]{2}{*}{ Narrative-discourse outline } & \multirow[t]{2}{*}{ 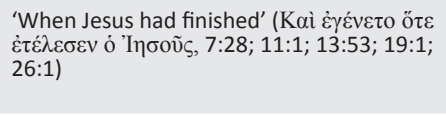 } & Toussaint (1980:24-30) & $\begin{array}{l}\text { 13:54-16:12; 16:13-19:2; \& 19:3-20:34; } \\
\text { or }\end{array}$ \\
\hline & & Carson $(1995: 51,55)$, Turner $(2008: 8-10)$ & $13: 53-17: 27 ; 18: 1-19: 2$ \& 19:3-23:39 \\
\hline Chiastic structure & $\begin{array}{l}\text { Large-scale chiasmus using the narrative- } \\
\text { discourse sequence }\end{array}$ & $\begin{array}{l}\text { Ellis (1974:viii-ix), } \\
\text { Combrink (1983:71), } \\
\text { Derickson (2006:426) }\end{array}$ & $\begin{array}{l}13: 53-17: 27 ; 18: 1-35 ; \& 19: 1-22: 46 \text {; or } \\
16: 21-20: 34 ; \text { or } \\
13: 53-17: 27 ; 18: 1-35 ; \& 19: 1-23: 39\end{array}$ \\
\hline \multicolumn{4}{|l|}{ Other: } \\
\hline a) Combination of approaches & Narrative-plot and narrative-discourse & Blomberg (1992:24-25) & $16: 21-17: 27 ; 18: 1-35 ; \& 19: 1-22: 46$ \\
\hline b) Rhetorical/Pesher & Ten citations of Isaiah as thematic cores & Patrick (2010:43, 71-72) & $14: 1-16: 12 ; 16: 13-21: 11$ \\
\hline
\end{tabular}

A. Rebuke and mercy: healing of demoniac 17:14-18

B. Private instruction to disciples: faith, praying, fasting 17:19-20[21]

C. Jesus foretells his death and resurrection 17:22-23

D. Sons of the king and the temple tax 17:24-27

E. Entering the kingdom: humility and greatness $18: 1-4$

F. Stumbling blocks 18:5-9

G. Despise no little one (parable) 18:10-14

H. Binding and loosing 18:15-20

I. Forgiveness and healing (parable) 18:21-19:2

$H^{\prime}$. Binding and loosing 19:3-12

G'. Forbid no little one 19:13-15

$F^{\prime}$. Stumbling block (possessions) 19:16-22

E'. Entering the kingdom: possible only with God 19:23-26

D'. Labourers of the owner of the vineyard (parable) 19:27-20:16

$C^{\prime}$. Jesus foretells his death and resurrection 20:17-19

$B^{\prime}$. Private instruction to disciples: suffering, serving, ruling 20:20-28

$A^{\prime}$. Rebuke and mercy: healing of two blind men 20:29-34

FIGURE 1: The chiastic structure in Matthew 17:14-20:34.

serve as inclusios, namely a Messianic miracle at the start of this section and another specific miracle that Jesus performed at the end of it $(17: 14-18 ; 20: 29-34$; cf. 19:2). ${ }^{3}$ The rhetorical situation is marked by, first, the journey motif or travelogue with movement down from the Mount of Transfiguration before going up to Jerusalem, together with other geographical markers $(17: 22,24 ; 19: 1$; 20:17, 29); second, explicit predictions by Jesus of his death and resurrection (17:22-23; 20:17-19); third, various incidents about humility and being reconciled (or not) to God or fellow believers through forgiveness (18:1-4; 18:5-9; 18:10-14; 18:15-20; 18:21-19:2; 19:3-12; 19:13-15; 19:16-22; 19:23-26); and fourth, references to greatness, rewards and authority in the Kingdom (17:19-20[21]; $18: 1-4 ; 19: 27-20: 16 ; 20: 20-28)$.

3.Fruchtenbaum (2016:143-155) highlights three miracles performed by Jesus that were 'different from anything else that had ever been performed', namely the healing of a Jewish leper ( $8: 2-4)$, the casting out of a demon that causes muteness healing of a Jewish leper ( $8: 2-4)$, the casting out of a demon that causes muteness Jews of that time held that these miracles could only be performed by the Jews of that time held that these miracles could only be performed by the
Messiah, hence they are called 'Messianic miracles' (cf. Jn 15:24; Fruchtenbaum 2016:155).

\section{The chiastic structure}

Based on the perceived parallel passages (to be discussed later), the chiastic structure (or rhetorical arrangement) that has been identified is shown in Figure 1.

\section{Evaluation of the chiastic structure}

To a person with a chiastic hammer, everything looks like a parallel nail. How can one avoid 'imagining chiasmus where it was never intended'? (Blomberg 1989:5). As noted in the introduction, the first of nine criteria identified by Blomberg (1989) has been met, but the remaining eight criteria are used to evaluate the identified chiastic structure:

(2) There must be clear examples of parallelism between the two 'halves' of the hypothesized chiasmus ... (3) Verbal (or grammatical) parallelism as well as conceptual (or structural) parallelism should characterize most if not all of the corresponding pairs of subdivisions. ... (4) The verbal parallelism should involve central or dominant imagery or terminology, not peripheral or trivial language. ... (5) Both verbal and conceptual parallelism 


\begin{tabular}{|c|c|c|c|c|c|c|}
\hline \multirow{6}{*}{$\begin{array}{l}\text { Section } \\
A \& A^{\prime}\end{array}$} & \multicolumn{3}{|c|}{ Parallelism } & \multicolumn{3}{|c|}{$\begin{array}{l}\text { Central or dominant imagery/terminology: } \\
\text { words/ideas not found elsewhere within the identified chiastic structure }\end{array}$} \\
\hline & \multicolumn{6}{|c|}{ Synonymous parallelism indicated by '-'; antithetic parallelism by 'vs' and synthetic parallelism by ' $\approx$ ' } \\
\hline & Crowd (17:14) & - & Crowd $(20: 29,31)$ & $\begin{array}{l}\text { 'Lord, have mercy on my son' } \\
(17: 15)\end{array}$ & - & $\begin{array}{l}\text { 'Lord, have mercy on us, Son of David!' } \\
(20: 30,31)\end{array}$ \\
\hline & $\begin{array}{l}\text { Jesus rebukes his disciples for } \\
\text { their unbelief (17:17-18) }\end{array}$ & $\approx$ & $\begin{array}{l}\text { The crowd rebukes the two } \\
\text { blind men }(20: 31)\end{array}$ & $\begin{array}{l}\text { Specific Messianic miracle: healing } \\
\text { a demonised boy below the } \\
\text { Mount of Transfiguration }(17: 18)\end{array}$ & - & $\begin{array}{l}\text { Specific healing: two blind men while } \\
\text { going up to Jerusalem (20:34). }\end{array}$ \\
\hline & \multirow{2}{*}{$\begin{array}{l}\text { Jesus rebukes a demon, } \\
\text { exorcism takes place, resulting } \\
\text { in a healing (17:18) }\end{array}$} & \multirow[t]{2}{*}{ vs } & \multirow{2}{*}{$\begin{array}{l}\text { Jesus heals with compassion } \\
(20: 34)\end{array}$} & Little faith $(17: 17)$ & vs & Faith of two blind men (20:29-34) \\
\hline & & & & Reference to the 'Lord' $(17: 15)$ & - & References to the 'Lord' $(20: 30-31,33)$ \\
\hline \multirow[t]{3}{*}{$B \& B^{\prime}$} & $\begin{array}{l}\text { Private question of disciples } \\
\text { to Jesus }(17: 19)\end{array}$ & - & $\begin{array}{l}\text { Request by the mother of James } \\
\text { and John to Jesus }(20: 20)\end{array}$ & $\begin{array}{l}\text { Some disciples claim inability } \\
(17: 19)\end{array}$ & vs & Some disciples claim ability $(20: 22)$ \\
\hline & \multirow[t]{2}{*}{$\begin{array}{l}\text { Private instruction to Christ's } \\
\text { disciples (17:19-20[21]) }\end{array}$} & \multirow[t]{2}{*}{-} & \multirow[t]{2}{*}{$\begin{array}{l}\text { Private instruction to Christ's } \\
\text { disciples }(20: 25-28)\end{array}$} & $\begin{array}{l}\text { Lack of faith (and perhaps prayer } \\
\text { and fasting) concerning authority } \\
\text { to exorcise a demon of the } \\
\text { kingdom of darkness (17:19-21) }\end{array}$ & $\mathrm{vs} / \approx$ & $\begin{array}{l}\text { Lack of knowledge concerning } \\
\text { authority and position in the kingdom } \\
\text { of Christ }(20: 21-22,25-28)\end{array}$ \\
\hline & & & & Figurative mountain (17:20) & $\mathrm{vs} / \approx$ & In Your kingdom (20:21) \\
\hline \multirow[t]{2}{*}{$C \& C^{\prime}$} & Son of Man (17:22) & - & Son of Man (20:18) & $\begin{array}{l}\text { Jesus foretells his death and } \\
\text { resurrection }(17: 22-23)\end{array}$ & - & $\begin{array}{l}\text { Jesus foretells his death and } \\
\text { resurrection (20:17-19) }\end{array}$ \\
\hline & Gathering in Galilee (17:22) & $\approx$ & Going up to Jerusalem (20:17) & & & \\
\hline \multirow[t]{5}{*}{$D \& D^{\prime}$} & Pay $(17: 24)$ & - & Pay $(20: 8)$ & First (17:25) & - & First (19:30; 20:8-10, 16) \\
\hline & $\begin{array}{l}\text { Coin for temple-tax, } \\
\text { two-drachma tax }(17: 24,27)\end{array}$ & $\approx$ & $\begin{array}{l}\text { Coin for wages, denarius } \\
(20: 9-10,13)\end{array}$ & $\begin{array}{l}\text { Kings of the earth, with pejorative } \\
\text { connotations (17:25) }\end{array}$ & vs & $\begin{array}{l}\text { Son of Man on his glorious throne in } \\
\text { the Kingdom }(19: 28 ; 20: 1)\end{array}$ \\
\hline & $\begin{array}{l}\text { Implied reference to Jesus as } \\
\text { the Son of God (17:26) }\end{array}$ & $\approx$ & $\begin{array}{l}\text { Owner of the vineyard } \\
(20: 1,8,11)\end{array}$ & Sons of the king $(17: 25)$ & $\approx$ & $\begin{array}{l}12 \text { apostles to sit on } 12 \text { thrones } \\
\text { as well as other believers }(19: 28-29)\end{array}$ \\
\hline & Peter involved (17:24-27) & - & Peter asks a question (19:27) & & & \\
\hline & Parable in action $(17: 27)$ & - & Parable in words (19:30-20:16) & Not giving offense (17:27) & vs & Offense taken $(20: 2,11-15)$ \\
\hline \multirow[t]{2}{*}{$E \& E^{\prime}$} & $\begin{array}{l}\text { Humility or dependence on } \\
\text { God }(18: 4)\end{array}$ & vs & $\begin{array}{l}\text { Many possessions may result in } \\
\text { independence }(19: 23-24)\end{array}$ & $\begin{array}{l}\text { Enter into the Kingdom of Heaven } \\
(18: 3)\end{array}$ & - & $\begin{array}{l}\text { Enter into the Kingdom of Heaven/God } \\
(19: 23-24)\end{array}$ \\
\hline & $\begin{array}{l}\text { Greatness in the Kingdom } \\
(18: 1,4)\end{array}$ & vs & $\begin{array}{l}\text { Perceived greatness in the world } \\
\text { because of many possessions }(19: 22)\end{array}$ & & & \\
\hline \multirow[t]{2}{*}{$F \& F^{\prime}$} & $\begin{array}{l}\text { Causing to sin or causing to } \\
\text { stumble }(18: 6,7)\end{array}$ & $\approx$ & $\begin{array}{l}\text { Potential stumbling block of } \\
\text { trusting in possessions }(19: 22)\end{array}$ & Enter into life $(18: 8,9)$ & - & Enter into life (19:17) \\
\hline & & & & Eternal fire, fiery hell (18:8-9) & vs & Eternal life (19:16) \\
\hline \multirow[t]{2}{*}{ G \& G' } & Little ones $(18: 10,14)$ & $\approx$ & Children (19:13-14) & $\begin{array}{l}\text { Do not despise one of these little } \\
\text { ones }(18: 10,14)\end{array}$ & $\approx$ & $\begin{array}{l}\text { Do not forbid the children to come to } \\
\text { Me (19:13) }\end{array}$ \\
\hline & Implied access to God (18:10) & $\approx$ & Actual access to Jesus (19:14-15) & $\begin{array}{l}\text { Finding the one sheep who } \\
\text { wandered away (18:13) }\end{array}$ & $\approx$ & He laid his hands on them (19:15) \\
\hline \multirow[t]{3}{*}{$\mathrm{H} \& \mathrm{H}^{\prime}$} & $\begin{array}{l}\text { Procedure for addressing sins } \\
\text { among believers (18:15-17) }\end{array}$ & $\approx$ & $\begin{array}{l}\text { Permitted Mosaic procedure for divorce } \\
\text { between husband and wife }(19: 8-9)\end{array}$ & Binding and loosing (18:18) & $\approx$ & $\begin{array}{l}\text { Permitting or prohibiting divorce (19:3, } \\
\text { 8) }\end{array}$ \\
\hline & & & & Bound in heaven/earth (18:18) & $\approx$ & What God has joined together (19:6) \\
\hline & & & & Refuses to hear (18:17) & $\approx$ & Hard-heartedness (19:8) \\
\hline 1 & \multicolumn{6}{|c|}{ God's forgiveness and forgiveness between people. Healing } \\
\hline
\end{tabular}

FIGURE 2: Verbal and conceptual parallelism in Matthew 17:14-20:34.

should involve words and ideas not regularly found elsewhere within the proposed chiasmus. ... (6) Multiple sets of correspondences between passages opposite each other in the chiasmus as well as multiple members of the chiasmus itself are desirable. ... (7) The outline should divide the text at natural breaks which would be agreed upon even by those proposing very different structures to account for the whole. ... (8) The center of the chiasmus, which forms its climax, should be a passage worthy of that position in light of its theological or ethical significance. If its theme were in some way repeated in the first and last passages of the text, as is typical in chiasmus, the proposal would become that much more plausible. (9) Finally, ruptures in the outline should be avoided if at all possible. (pp. 5-8)

Figure 2 shows how the criteria relating to parallelism (criteria 2-5) are complied with in the identified chiastic structure.

Criteria six, seven and eight also appear to have been met: the chiastic structure has many corresponding sections or member sets (A-H; $\left.\mathrm{A}^{\prime}-\mathrm{H}^{\prime} ; \mathrm{I}\right)$; it divides 17:14-20:34 at natural breaks recognised by most commentators; and the centre of the structure deals with forgiveness, reconciliation and healing, a subject that ties together much of what precedes and follows section I. Moreover, whereas sections A and $\mathrm{A}^{\prime}$ highlight specific instances of healing, the chiastic centre (I) focuses on spiritual healing through forgiveness and also contains a general reference to healing (19:2). Regarding criterion nine, it bears pointing out that there are no ruptures in the chiastic structure. Admittedly, some of the perceived parallels seem more obvious than others, and thus it is not asserted that the identified chiastic structure is the 'final answer' to this portion of Scripture. It does, however, appear that most of the nine criteria of Blomberg (1989:5-8) have been met. The identified chiastic structure in 17:13-20:34 is therefore offered as an alternative to the many other proposals that exist. A discussion of the parallel sections of the identified chiastic structure follows.

\section{Discussion of the chiastic structure in Matthew 17:14-20:34}

The aim of discussing the chiastic structure in 17:14-20:34 is to briefly clarify the meaning of its parallel elements and to 
indicate whether these pairs are linked synonymously (by way of comparison or correspondence), and/or antithetically (contrast) and/or synthetically (conceptually and thematically).

\section{Sections $A(17: 14-18)$ and $A^{\prime}(20: 29-34)$}

In sections $\mathrm{A}$ and $\mathrm{A}^{\prime}$, Jesus performs a specific healing in response to a humble entreaty. In the first case, a distraught father kneels before Jesus and asks, 'Lord, have mercy on my son' (17:15 - NKJV), whereas in the second case, two blind men persistently cry out, 'Have mercy on us, O Lord, Son of David!' (20:30-31). Moreover, Jesus rebukes some of his disciples because of their lack of faith (17:17), whereas in the corresponding section, the crowd rebukes the two blind men who are exhibiting faith (20:31). Both the demonised boy and the two blind men had to be brought to Jesus $(17: 16 ; 20: 32)$. In contrast to the 'faithless generation' with whom Jesus had been for some time (17:17), these blind men immediately show spiritual insight by not only identifying Jesus as the Son of David, but also trusting him to give them physical sight (20:3334). They then follow Jesus out of Jericho, acting as two more witnesses of the Lord in Jerusalem. In the chiastic structure under discussion, both sections $\mathrm{A}, \mathrm{A}^{\prime}$ and the chiastic centre (I) contain specific entreaties, examples of Jesus healing and the only references to 'Lord' (17:14-15; $18: 21,26 ; 20: 30-31,33) .^{4}$

\section{Sections B (17:19-20[21]) and B' (20:20-28)}

Exercising the authority given to the disciples of Christ is emphasised in sections B and B'. In the first section, 'little faith' - but also a lack of prayer and fasting if 17:21 is authentic - prevents some of the disciples from exorcising a demon (17:19-20[21]; cf. 10:8), whereas in the parallel section, some of them fail to understand how authority is granted in Christ's kingdom (20:21) or that it should be exercised in humility (20:22-20:28). Jesus is the supreme example of service, and his suffering precedes his exaltation in glory (20:28; cf. 24:30; 25:31). In 17:19-20[21], the moving of the mountain does not refer to the physical Mount of Transfiguration. In their discussion of 17:20, Davies and Allison (1991:728) note that 17:20 contains 'a paradoxical juxtaposition: the insurmountable is accomplished by the infinitesimal'. If disciples of Jesus exercise faith as small as a mustard seed, what is impossible for them can be achieved by God's power (France 2007:662-663). Matthew 20:20-28 also contains a paradoxical juxtaposition: greatness in the kingdom is not obtained by exercising lordship over others, but rather by serving them like a slave (20:25-28). In both sections B and B', God gives the authority, whether it will be used to oppose the kingdom of darkness when exorcising a demon (17:19-20[21]) or to benefit the kingdom of Christ (20:20-28).

\footnotetext{
4. Hagner (1995:501-502) notes that the number of healing miracles decreases as the Gospel of Matthew progresses. The only other specific healing after 20:34 is mentioned in 21:14.
}

\section{Sections C (17:22-23) and C' (20:17-19)}

Jesus' prediction in Galilee about his death and resurrection is repeated and elaborated as he is going up to Jerusalem (17:22-23; 20:17-19). McClister (1996:552) also views 17:22-23 and 20:17-19 as chiastic pairs, adding that these passion predictions form a 'hermeneutical inclusio' that sets the 'interpretive tone for the episodes, sayings, parables and so forth, in between'. ${ }^{5}$ Sections $C$ and $C^{\prime}$ emphasise the humility of Christ and his service to the point of death.

\section{Sections D (17:24-27) and D' (19:27-20:16)}

Peter is involved in both sections $\mathrm{D}$ and $\mathrm{D}^{\prime}$. Both sections refer to payment with a coin, and an implied reference to Jesus as the Son of God can be matched to the owner of the vineyard. Even though the sons of the King are exempt from paying the temple tax, Jesus and Peter do so to avoid giving offense (17:27). In the parable of the landowner and the labourers, however, some workers take offense at the landowner for the payment they received (20:11-12). Blomberg (1992:269, 271; cf. Turner 2008:429) probably speaks for many when he states that the section containing the miracle of the coin is 'one of the most difficult to understand, both in terms of the significance of certain details and in light of its location in this context'. Other than for some formal reasons already noted above, why can sections $\mathrm{D}$ and $\mathrm{D}^{\prime}$ be viewed as pairs in the chiastic structure? First, the position of the kings of the earth's sons (17:25) can be juxtaposed to the situation in the age when all things are renewed, when the Son of Man sits enthroned as King with not only the 12 apostles on 12 thrones judging the 12 tribes of Israel, but also with all his other followers (19:28-29). Second, Bailey and Constable (1999:36; cf. Carson 1995:395) suggest that the miracle of the coin may hint at the 'transition from temple worship that would come as a result of His death and resurrection. A new era in the economy of God was about to begin.' The parable of the landowner and the labourers may be viewed as eschatological (Davies \& Allison 1997:67-68; cf. also Blomberg 1992:304), covering a time period in the vineyard that stretches from the cross until the second coming of the Lord Jesus Christ when his servants will be rewarded, that is, when the harvest has been completed. Labourers will be rewarded by God who is just, sovereign, gracious and good (20:13-16).

\section{Sections E (18:1-4) and E' (19:23-26)}

Both sections $\mathrm{E}$ and $\mathrm{E}^{\prime}$ contain an emphatic declaration by Jesus: 'Truly, I say to you' (18:3) or, 'Assuredly I say to you' (19:23-24). The declaration in section $\mathrm{E}$ refers to the impossibility of entering the Kingdom without a radical change towards childlike humility and indifference to status (18:3-4). Section E' contains a similar message: it is impossible for human beings to enter the Kingdom on their own merits or to save themselves - but it is possible for God to save

5.The pairing of Matthew $17: 22-23$ and $20: 17-19$ is the only agreement between the chiastic structure proposed by McClister (1996) and that under discussion in this article. 
human beings who are dependent on him. He is the One who allows them entrance into the Kingdom (19:24-26). Children trust and depend entirely on others; likewise, disciples are to depend entirely on God for salvation (18:3; 19:25-26). Contrary to the false teaching of that time, 'riches are not always proof of God's approval' (Turner 2008:473). Greatness in the Kingdom is therefore not predicated on worldly possessions, personal virtues or achievement, but on humility (19:23-26; cf. 18:1). What Jesus teaches in $\mathrm{E}$ is to some extent reiterated in $\mathrm{E}^{\prime}$.

\section{Sections $F(18: 5-9)$ and $F^{\prime}(19: 16-22)$}

The emphasis in section $\mathrm{F}$ is on stumbling blocks that could cause a little one to sin such as rejection, the world or actions of the little ones themselves (18:5-9). In section $\mathrm{F}^{\prime}$, riches acted like a stumbling block in a young man's life, preventing him from following Jesus (19:16-22). Since the issue is to 'enter life' or 'eternal life' (18:8-9; 19:16), radical action is required to either avoid stumbling blocks or to be rid of them altogether. What Jesus teaches in F is, to some extent, demonstrated in $\mathrm{F}^{\prime}$.

\section{Sections G (18:10-14) and G' (19:13-15)}

In section $\mathrm{G}$, the importance of each 'little one' to God the Father is stated by Jesus, explained in a parable and then applied (18:10-14). In the corresponding parallel section $\left(\mathrm{G}^{\prime}\right)$, this is demonstrated when little children are brought to Jesus and he lays his hands on them (19:13-15). Again, what Jesus teaches in $\mathrm{G}$ is, to some extent, reiterated and demonstrated in $\mathrm{G}^{\prime}$. Both sections contain a strong warning: 'Take heed that you do not despise one of these little ones, for I say to you that in heaven their angels always see the face of My Father who is in heaven' (18:10), and 'Let the little children come to $\mathrm{Me}$, and do not forbid them; for of such is the kingdom of heaven' (19:14). Evidently, the first warning was not appreciated by Jesus' disciples, for as Blomberg (1992:295) aptly remarks, 'Jesus' "little ones" (the disciples) compare unfavorably with real "little ones" (the children)'. Hagner (1995) likewise remarks that:

Jesus is not too busy even on the way to the cross to bless the little ones who can by example teach the 'little ones' who are the adult members of the community of disciples. He blesses alike the children and the childlike. (p. 553)

\section{Sections H (18:15-20) and H' (19:3-12)}

Section $\mathrm{H}$ is concerned with reconciliation between believers in the family of God (18:15-20), and section $\mathrm{H}^{\prime}$ highlights the nuclear family in the matter of marriage and divorce (19:3-9). Whereas 18:18-19 mentions binding and loosing, 19:3-12 provides a Mosaic example of binding and loosing in terms of marriage and divorce as well as teaching about singleness for the sake of the Kingdom.

Edersheim (1993:531-532) notes that Jesus gives his apostles the authority to legislatively bind (forbid) and loose (permit) as well as to judicially bind (hold liable for punishment) and loose (set free from punishment). The apostles exercised this authority under God, the Holy Spirit, from Pentecost until the last of them died (cf. Ac 5:1-11; 15; 1 Cor 5:1-13). ${ }^{6}$ Local churches cannot add to or subtract from the inspired New Testament (legislative authority), but they must exercise discipline in accordance with the Law of Christ (judicial authority) (Scholtz 2016:6).

This authority to 'bind and loose' in both the legislative and judicial sense was claimed by rabbis to have belonged to the rabbinic office: 'no other terms were in more constant use in Rabbinic Canon-Law than those of 'binding' and 'loosing" (Edersheim 1993:531). When the Pharisees came to test Jesus (19:3), they wanted Jesus to contradict some Pharisaic interpretation of the Law of Moses which could then become grounds for treating him just like they treated John the Baptist (Carson 1995:411). The issue 'was not divorce itself, the right to which they took for granted, but rather the justifiable grounds for divorce' (Hagner 1995:547). Previously, Moses exercised authority under God to bind and to loose. Because of people's hardened hearts, Moses permitted (or 'loosed') divorce - but he did not command it. 'God's original purpose for marriage overrides the Mosaic concession for human sin' (Turner 2008:461). God's intention has always been for marriage to be permanent and so no human being must separate what God has joined together (19:6; cf. 18:18). Similar to other sections in this chiastic structure, what is taught and authorised in section $\mathrm{H}$ (reconciliation between believers, to bind and to loose) is demonstrated in $\mathrm{H}^{\prime}$.

\section{Section I (18:21-19:2)}

Matthew 18:21-35 is worthy of its place in the chiastic centre, as it undergirds much of what precedes it and anticipates much of what is to follow. Between the Mount of Transfiguration and Jerusalem, Christ was on his way to give his life as a ransom for many. On the way to the cross, he heals, instructs his disciples regarding authority, avoids giving offence, teaches about humility and greatness, warns about stumbling blocks and explains how little ones are to be treated. In section I, God's forgiveness of a person is shown to be the model for personal mutual forgiveness (Nel 2015:5). However, such forgiveness is based on the death and resurrection of Jesus being achieved in Jerusalem during his first coming (cf. also 17:22-23; 20:17-19, 28). In the proposed structure, Jesus therefore brings not only physical healing (A, 17:14-18; $\mathrm{A}^{\prime}$, 20:29-34; I, 19:2), but also spiritual healing through forgiveness (section I, 18:21-35). Without God's forgiveness or personal mutual forgiveness, many of the other lessons noted in this structure, namely authority, suffering, avoiding offense, humility, service and suffering will be significantly weakened (cf. also Hagner 1995:541; Turner 2008:452). On the way to the cross, Jesus demonstrates how he welcomes children, reveals a stumbling block in a person's life and teaches about whole-hearted dependence 6.The authority to bind and loose was not passed on by way of apostolic succession and Peter is not the first in a line of many popes. 


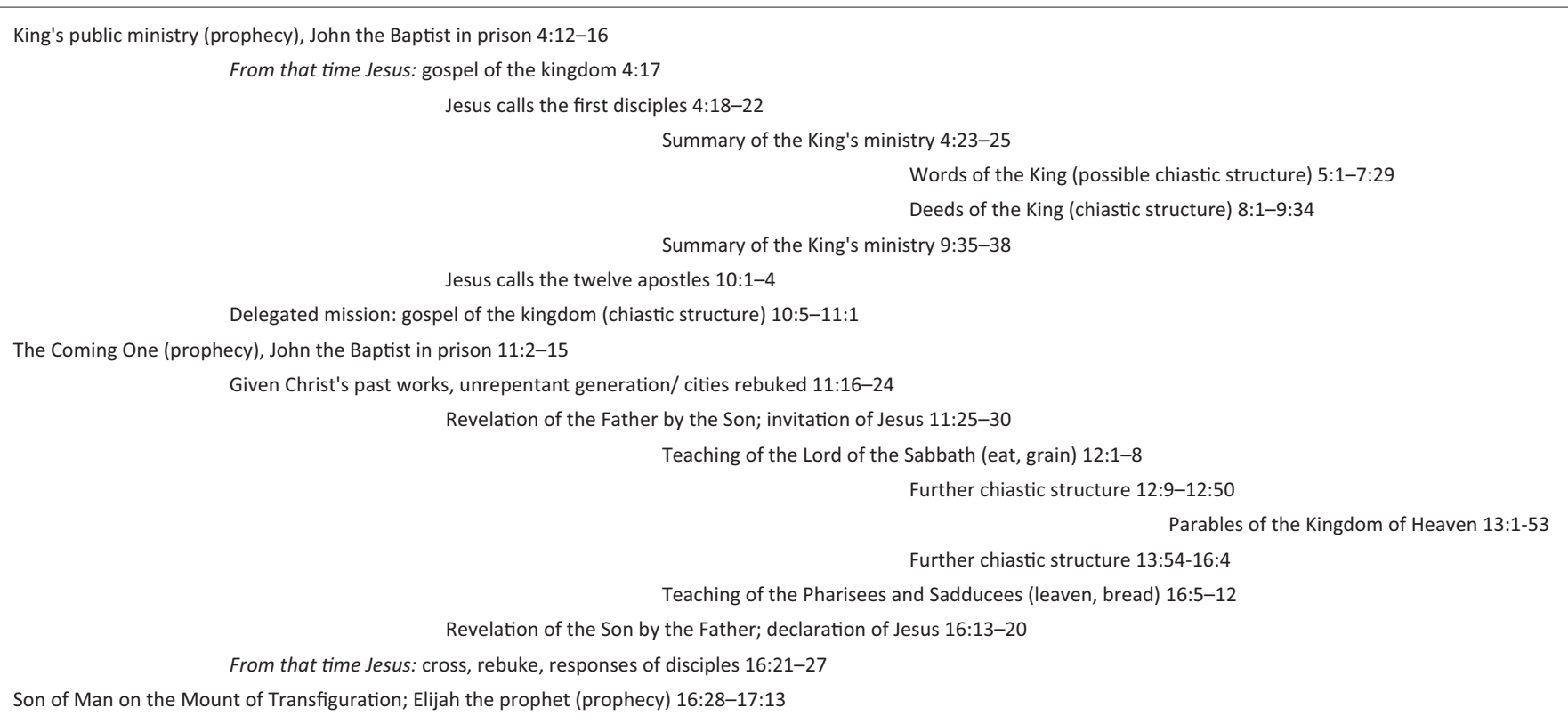

FIGURE 3: Summary of chiastic structures in Matthew 4:12-17:13.

on God as well as about rewards and authority. All this is, again, predicated on God's forgiveness that is the basis for forgiveness between people. Jesus then once again healed many (19:2; cf. 17:14-18; 20:29-34).

\section{Fitting Matthew 17:14-20:34 into the larger structure of 16:28-25:46}

As noted earlier, if a smaller topical study is to be more useful, its place in the larger thought or movement of the entire text (Matthew's Gospel in this case) should be indicated. While Scholtz (2016:1-10) argues that a previous chiastic structure in Matthew ends at 16:28-17:13, Luz (2007:9) holds that 21:1-25:46 constitutes 'clearly recognizable units'. If so, can 17:14-20:34 fit into 16:28-25:46? What follows cannot be a detailed defence of another large chiastic structure, but it is an attempt to show that 17:14-20:34 can plausibly fit into $16: 28-25: 46 .^{7}$

Some transitional pericopes unquestionably look back to preceding passages while also anticipating what is yet to come (Weren 2006:180-181; Luz 2007:4-5; Patrick 2010:59). Accordingly, it is worth considering important transitional sections in Matthew not only as 'headings' in large chiastic structures, but also as 'endings' of previous structures. For example, the glorious appearance of Christ on the Mount of Transfiguration (16:28-17:13) recalls not only the great Light who commenced his public ministry when John the Baptist was put in prison (4:12-16; cf. Davies \& Allison 1991:705), but also John the Baptist in prison asking questions about the coming One and the Kingdom (11:2-15). These transitional passages $(4: 12-16 ; 11: 2-15 ; 16: 28-17: 13)$ may be used both as macro-headings and endings in Matthew, for they connect the King and his ministry to a forerunner, whether it be the 7.See Scholtz $(2015 ; 2016)$ for a detailed defence of the chiastic structures of $11: 2-$ $17: 13$ and 21:1-25:46. forerunner of his first or second advent (cf. Scholtz 2016:9). Figure 3 illustrates this, providing a summary of earlier sections of Matthew and using important transitional pericopes as both headings and endings of various chiastic structures.

If 16:28-17:13 serves not only as an ending of a previous chiastic structure, but also as a heading for the next, then the movement in 16:28-25:46 is from the vision of the Son of Man coming in his Kingdom on the Mount of Transfiguration, then down to Jerusalem and arriving in Jerusalem not only during his first earthly ministry (21:1-17), but also looking ahead to his prophesied return in glory at the second coming to the earth (24:29-30; 25:31-46; Scholtz 2015:3). Figure 4 shows how the chiastic structure of 17:14-20:34 can plausibly fit into the larger movement of thought and structure of 16:28-25:46.

At the end of Matthew, Jesus commands the eleven apostles to teach disciples to 'observe all the things that I have commanded you' (28:20). This disciple-making process started in all earnest 50 days after the resurrection of Jesus, that is, on the day of Pentecost (Ac 2:1). Most of the first disciples were Jewish, because the gospel of Christ was first preached in Jerusalem (Ac 1:8; 2-7), only later in Judea and Samaria (Ac 8) before being preached to Gentiles all over the world (Ac 10-28). Dorsey (1999:16) cogently argues and demonstrates that 'symmetry, parallelism, and structured repetition' appear throughout the Old Testament literature. Between the time that the great commission was given and the time when the Gospel of Matthew was inspired by the Holy Spirit, one can reasonably expect the 12 Jewish apostles to have taught Jesus' commands to those first Jewish disciples (Ac 1:8; 2-7) using symmetry, parallelism and various oral techniques, because the Jews may well have been familiar with these structuring conventions 


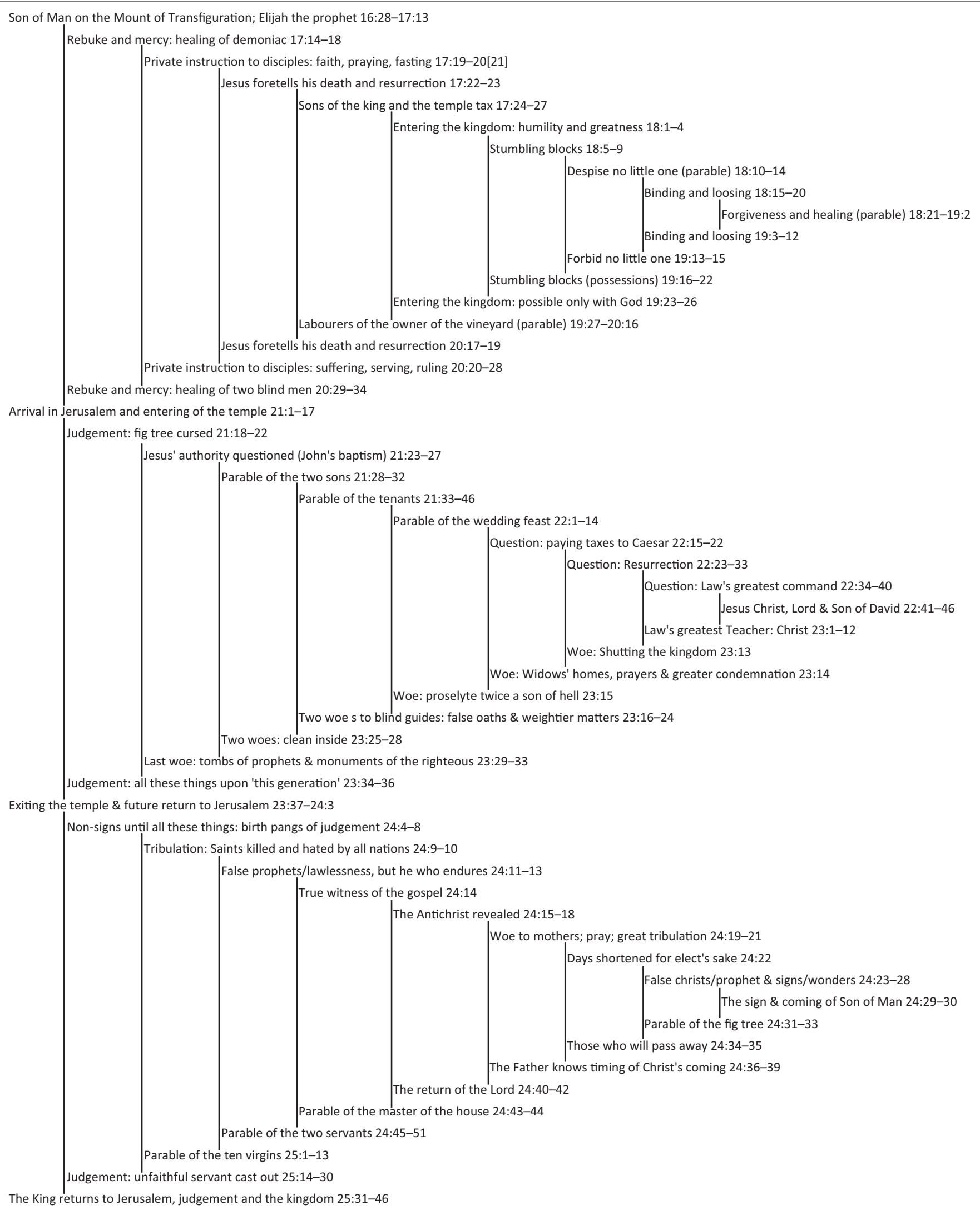

FIGURE 4: Chiastic structures in Matthew 16:28-25:46.

found in the Hebrew Scriptures. Prior to the inspiration of the first New Testament documents, the teaching of the apostles must have been orally, but if taught by using parallelisms, known to those original listeners, it would 'aid in memorising oral material' (McClister 1996:550-551). It would also focus attention on Jesus' key teaching points the very things Jesus commanded the apostles to do when making disciples. 
The chiastic structures in Figures 2 and 3 emphasise the first and second comings of Jesus Christ, the forerunners to each advent as well as the kingdom programme during the interval between Christ's two comings. These structures may thus contribute to an understanding of the overall message and purpose of the Gospel of Matthew. In agreement with Toussaint (1980), the purpose of Matthew's Gospel is to explain God's kingdom programme as it relates to Jesus, to Israel and to the Church:

Matthew then presents the kingdom program in three aspects. First, the earthly literal kingdom was offered to Israel in the person of Jesus, the Messiah, at His first coming. Second, the kingdom was postponed because Israel rejected its Messiah. This postponed kingdom will be established at Christ's second coming. Third, Christ Jesus is now engaged in building His church, composed of those who in this age are the heirs of the kingdom. (p. 20)

\section{Conclusion}

Compared to other proposals mentioned in the introduction, why is the identified chiastic structure in 17:14-20:34 possibly a worthy alternative? First, while not claiming it is perfect, the chiastic structure in 17:14-20:34 seems to fit the various pericopes of this passage well and meet most of Blomberg's criteria (1989:5-8), if not all. It is submitted that this structure is the result of studying the text; it is not the result of an overall structuring principle brought to the text. Moreover, by identifying transitional pericopes as both headings and endings for larger sections in Matthew, it has also been shown that 17:14-20:34 can plausibly fit into the larger movement of Matthew's thought in 16:28-25:46 (if not also in $4: 12-25: 46)$.

Second, while the five major discourses in Matthew undoubtedly have an important significance for the structure of Matthew, these discourses 'do not move the action along' (Luz 2007:12). If the discourse in Matthew 10 is not the centre 'of its own main section' (Luz 2007:10), then, from a structuring perspective, the discourse in chapter 18 also need not necessarily be a separate section (cf. McClister 1996:557). It may even be argued that, especially as it is part of a travelogue, chapter 18 consists of teaching material to be used as examples as the journey continues to Jerusalem. If so, then it makes structural sense not to view 18:1 and 19:1 as major sections or narrative breaks. As a result, it becomes easier to notice that much of what is taught in 18:1-20 (E-H) is reiterated, demonstrated or repeated in 19:3-26 (H'-E').

Third, both the Markan and geographical approaches to the overall structure of Matthew assume that a geographical turning point is reached in 16:21-28. Mount Hermon is probably the site of the transfiguration (Bailey \& Constable 1999:35; cf. also Scholtz 2016:5). Not only is Caesarea Philippi (16:13) near its foot, but Mount Hermon is also the highest mountain in Israel. If the transfiguration did indeed take place on Mount Hermon, Jesus would have first moved north (17:1) after the passion announcement (16:21; cf. also 17:12), before going south to Jerusalem and the cross. Should outlines of Matthew that are based on the Markan or geographical approach not take this into account?

Fourth, the narrative-plot outline approach to the Gospel of Matthew is built on the twice-repeated phrase, 'from that time Jesus began' (4:17; 16:21; Kingsbury 1975:1-37; Bauer 1998:97). It is not, however, all that clear that this redactional phrase is so pivotal in Matthew (Carson 1995:50). After all, the same phrase ('A $\pi$ ò $\tau$ ó $\tau$ ) again appears in 26:16 and, from a structuring perspective, little is made of this reference. Perhaps Gundry (1982:10; cf. Patrick 2010:48) is correct in saying that ' $4: 17$ and 16:21 seem to mark turning points in Jesus' life, not in Matthew's gospel'. In fact, as Figure 3 intimates, 4:17 and 16:21 may be inclusios in a larger, structural pattern in Matthew.

In conclusion then, the chiastic structure of 17:14-20:34 has been identified, evaluated and briefly discussed as a possible alternative to other structures. This article has also placed 17:14-20:34 into the larger thought or movement of 16:28 25:46. Maybe an overarching structure in Matthew should focus on forerunners, but, more importantly, on Jesus Christ, whether it be the first or the second advent of the Lord. Between the Mount of Transfiguration and Jerusalem and beyond, on his way not only to the cross, but ultimately also to the crown, the Lord Jesus Christ forgives, heals with compassion, teaches his disciples and demonstrates humility.

\section{References}

Bailey, M. \& Constable, T., 1999, Nelson's New Testament survey, Thomas Nelson, Nashville.

Bauer, D.R., 1988, The structure of Matthew's Gospel, Almond Press, Sheffield.

Blomberg, C.L., 1989, 'The structure of 2 Corinthians 1-7', Criswell Theological Review 4(1), 3-20.

Blomberg, C.L., 1992, The New American commentary: Matthew, vol. 22, Broadman Press, Nashville.

Carson, D.A., 1995, The Expositor's Bible Commentary with the New International Version of the Holy Bible: Matthew chapters 1 through 12 \& Matthew chapters 13 through 28, Zondervan Publishing House, Grand Rapids.

Combrink, H.J.B., 1983, 'The structure of the Gospel of Matthew as narrative', Tyndale Bulletin 34(1), 61-90.

Davies, W.D. \& Allison, D.C., 1991, A critical and exegetical commentary on the Gospel according to saint Matthew, vol. 2, T\&T Clark, Edinburgh.

Davies, W.D. \& Allison, D.C., 1997, A critical and exegetical commentary on the Gospel according to saint Matthew, vol. 3, T\&T Clark, Edinburgh.

Derickson, G.W., 2006, 'Matthew's chiastic structure and its dispensational implications', Bibliotheca Sacra 163(652), 423-437.

Dorsey, D.A., 1999, The literary structure of the Old Testament: A commentary on Genesis-Malachi, Baker Academic, Grand Rapids.

Edersheim, A., 1993, The life and times of Jesus the Messiah: New updated version, Hendrickson Publishers, Peabody.

Ellis, P.F., 1974, Matthew: His mind and his method, The Liturgical Press, Collegeville.

France, R.T., 2007, The Gospel of Matthew, Eerdmans, Grand Rapids.

Fruchtenbaum, A.G., 2016, Yeshua: The life of Messiah from a Messianic Jewish perspective, vol. 1, Ariel Ministries, San Antonio.

Gundry, R.H., 1982, Matthew: A commentary on his handbook for a mixed Church under persecution, Eerdmans, Grand Rapids.

Hagner, D.A., 1995, Word biblical commentary: Matthew 14-28, vol. 33B, Thomas Nelson, Nashville.

Kingsbury, J.D., 1975, Matthew: structure, Christology, kingdom, Fortress Press, Minneapolis.

Nel, M.J., 2015, 'Interpersoonlike vergifnis in Matteus 18:15-35', In die Skriflig 49(2), Art. \#1935, 8 pages. http://doi.org/10.4102/ids.v49i2.1935

Luz, U., 2007, Matthew 1-7, Fortress Press, Minneapolis.

McClister, D., 1996, "Where two or three are gathered together": Literary structure as a key to meaning in Matt 17:22-20:19', Journal of the Evangelical Theological Society 39(4), 549-558. 
McCuistion, P.R., 2013, 'Covenant, Christology, and Kingdom as context in Matthew's use of plēróó', Unpublished PhD thesis, North-West University, Potchefstroom, use of pleroo, Unpublished PhD thesis, North-West University, Potchefstro
viewed 21 October 2016, from http://dspace.nwu.ac.za/handle/10394/9175

Morris, L., 1992, The Gospel according to Matthew, Eerdmans, Grand Rapids.

Patrick, J.E., 2010, 'Matthew's pesher Gospel structured around ten messianic citations of Isaiah', The Journal of Theological Studies 61(1), 43-81.

Scholtz, J.J., 2015, 'Behold the glory of the King: The chiastic structures of Matthew $21-25$ ', In die Skriflig 49(1), Art. \#1856, 8 pages. http://doi.org/10.4102/ids. v49i1.1856
Scholtz, J.J., 2016, 'One Messiah, two advents, three forerunners: The chiastic structure of Matthew 11:2-17:13', In die Skriflig 50(1), Art. \#2125, 10 pages. http://doi.org/10.4102/ids.v50i1.2125

Toussaint, S.D., 1980, Behold the King: A study of Matthew, Kregel Publications, Grand Rapids.

Turner, D.L., 2008, Baker exegetical commentary on the New Testament: Matthew, Baker Academic, Grand Rapids.

Weren, W.J.C., 2006, 'The macrostructure of Matthews' Gospel: A new proposal', Biblica 87(2), 171-200. 